\title{
Digital Transformation of SMEs Financial Behavior in the New Normal Era
}

\author{
Gendro Wiyono ${ }^{1}$, Kusuma Chandra Kirana ${ }^{2 *}$ \\ 1,2Universitas Sarjanawiyata Tamansiswa, Indonesia, \\ *Corresponding Author: kusumack@ustjogja.ac.id
}

\begin{abstract}
This study aims to determine whether there has been a digital transformation of financial behavior in the use of fintech by micro, small and medium enterprises (SMEs) in Indonesia with the Covid-19 Pandemic. The study used a population of SMEs in all provinces, while the sample collected was 84 SMEs from 19 provinces in Indonesia. Data analysis using variance-based SEM with SmartPLS 3.2.9 software tools. The results show that the Covid-19 pandemic has an effect on SMEs (old behavioral intention) in using fintech, and this is a strengthening of the influence on new behavior in using fintech (new behavioral intention). Meanwhile, the New Normal policy also has a positive and significant effect on the current behavior of using fintech (new behavioral intention). As for the new normal as a moderating variable, old behavioral intention to new behavioral intention has no significant role, this is because before the new normal, many SMEs used fintech. Suggestions for SMEs to continue to take advantage of fintech in carrying out their business activities to avoid the impact of Covid-19 and the smooth running of their business.
\end{abstract}

Keywords

: The Covid-19 Pandemic; Old Intention Behavior; New Normal; New Intention Behavior

JEL Classification : G21, G41

\section{INTRODUCTION}

The corona virus pandemic presents its own challenges for business people, especially the SMEs. According to the Indonesian Retail Entrepreneurs Association (2020), changes in consumer behavior patterns caused by the Covid-19 pandemic have a direct impact on modern retail. The incident occurred starting on December 31, 2019, when a similar case with an unknown pneumonia emerged in Wuhan, China (Liang, 2020). This case was caused by a virus known as Covid-19 (Corona Virus Desese-2019). The impact of the Covid-19 pandemic has changed various aspects of human life. Covid-19 is the name of the new virus given by the World Health Organization (WHO,2020). Initially, the transmission of this virus cannot be determined whether it can be transmitted between humans. Finally, it was confirmed that pneumonia transmission could be transmitted from human to human (Relman, 2020). Coronavirus or Severe Acute Respiratory Syndrome Coronavirus 2 (SARS-CoV-2) is a virus that attacks the human respiratory 
system. This viral infection can cause minor problems with the respiratory system, severe lung infections, and even death.

To overcome the spread of Covid-19, the Indonesian government issued Government Regulation (PP) Number 21 of 2020 concerning Large-Scale Social Restrictions (LSRR) related to accelerating the handling of Coronavirus disease 2019 (Covid-19). LSRR is a prohibition on the activities of certain residents in areas suspected of having Covid-19 to prevent its spread. LSRR was carried out during the 14 days incubation period. If there is evidence of spreading in the form of a new case, it can be extended within 14 days from the discovery of the last case. The Covid-19 pandemic caused a shift in the intention of economic transaction behavior which eventually mapped the overall change in the trade scenario that we know as the new normal (Meita, 2020).

The new normal is a new order to adapt to Covid-19, which is a new habit based on adaptation to foster a clean and healthy lifestyle. This protocol is not only in the economic sector, but also in the fields of education and religion, so that the addition of positive cases can be suppressed (Dipna, 2020). The workplace as a locus of interaction and community gathering is a risk factor that transmission should be anticipated. Dewi (2020) research results show that currently some offices no longer enforce a work from home policy following the new normal rules, but still apply protocol rules. However, using public transportation still needs to be watched out, because on public transportation you will definitely meet and come into contact with many people whose hygiene history is unknown.

The occurrence of the Covid-19 pandemic has indeed caused a shift in the intention of SME business transaction behavior from before the Covid-19 pandemic to a new normal condition. According to Aditya \& Wardhana (2018), behavioral intention is a person's desire to carry out a certain behavior. Behavioral intention is a good predictor of SME behavior in using digital technology to make transactions during the Covid-19 pandemic. The results of research before the Covid-19 pandemic (Old Behavioral Intention Using fintech) show that the benefits felt by SMEs in using fintech have a positive and significant effect on behavioral using finteh (Nursiah, 2017; Bangkara, Putu, \& Harta, 2016; Putri \& Jumhur (2019). On the other hand, however, The Perceived Easy of use did not increase their interest using fintech (Gendro \& Kusuma, 2020). Furthermore, it is related to new behavioral intention after the occurrence of Covid-19 became a new normal, referring to research according to Aditya \& Wardhana (2018), behavioral intention to use fintech will have the same tendency, especially if it is related to the adaptations that must be carried out by SMEs during a pandemic or new normal conditions. Referring to Naufal's opinion (2020), the solution for SMEs in the new normal era lies in integration, such as integration of payment systems using fintech. Of course, this integration can be used immediately if SMEs join the marketplace. By implementing the digital economy, especially the use of fintech, it is hoped that SMEs will be able to survive in a new normal situation. The positive impact, SMEs can also sell their products to a wider market (Yan, 2015; Ahlstrom et al., 2020).

The coronavirus pandemic has changed significantly the way businesses interact with customers. Therefore, it is important for SMEs to map patterns of changing consumer behavior in this era, including the wants, hopes and needs of consumers in living a new normal life. One example is consumer shopping behavior which is believed to avoid physical encounters. Online shopping will be an option once this pandemic is 
over. Nielsen's (2020) study on Indonesian consumer behavior also reports that 30 percent of respondents stated that they had increased online shopping activity and 40 percent said they would continue to make purchases online even after the pandemic ended, which is in line with the new normal concept. In order to deal with the global pandemic and the current new normal, businesses must find ways to stay connected to their customers. Customer interest in online shopping mode also directs SMEs to expand their coverage into the digital world with all the conveniences offered.

The occurrence of the conditions above has created an extraordinary role for the digital economy as a form of industrial revolution 4.0 during the Covid-19 pandemic. The limited physical interaction between humans causes various forms of economic transactions to be carried out remotely and online by utilizing digital technology. According to Agus (2020) who cites Don Tapscott's opinion, who first put forward the idea of a digital economy in 1995, he is certainly happy that the digital economy has an important role and impact in this pandemic era. Meanwhile, SMEs that still rely on traditional business models tend to find it increasingly difficult to develop. The digital economy is expected to be able to restore the performance of SMEs in the new normal era by adopting digital technology. One of the shortcuts that can be taken is collaboration with e-commerce companies in the marketing of goods and digital economy payment systems which have a major impact on the development of SME businesses. Transfer of funds or payment of financial transactions can be done online with a digital application. The Covid-19 pandemic has changed the pattern of people's behavior in making payment transactions towards safer online payments (Tut, 2020). The era of the digital economy has opened the widest possible opportunity for payment system innovation, so that payment fintech was born as the main competitor of banking in providing payment transaction services (Ozili, 2020). The growth of payment fintechs such as GoPay, OVO, Dana and others is very fast and provides another alternative for people to get payment services other than banks (Fu \& Mishra, 2020).

The facts show that the world is undergoing a transformation from a traditional economy to a digital economy for many reasons. First, the use of digital technology will improve the production process and increase efficiency. Second, human dependence on information and communication technology cannot be separated so that as much human activity as possible is carried out through digital technology. Third, the social distancing factor in the new normal era has made physical contact more attractive to the public. Fourth, empirical evidence from various studies and research shows that the adoption of digital technology has a strong correlation with world economic growth. Fifth, economic globalization is still needed by all countries to support the welfare of all mankind so that in the future the digital economy will become the foundation of connectivity and trade across countries (Agus, 2020). The Covid-19 pandemic indirectly has a positive impact on the transaction patterns of consumers and SMEs. The shift in shopping trends to digital platforms is mainly due to the drastic decline in community mobility, as well as the application of Large-Scale Social Restrictions (LSSR) to break the chain of spreading the corona virus. In addition, the number of merchant partner accounts on e-commerce platforms has increased since the pandemic. Many experts predict the emergence of a shift in the trend of transaction patterns, from offline to online online (Cindy \& Agung, 2020; Javed, 2020). The presence of fintech and digitalization of the financial sector are things that need to be prepared in adapting to new habits habits (Benuf, 2020; Giese \& Haldane, 2020). Furthermore, what are the views of SMEs, the results of research by 
Gendro \& Kusuma (2020) provide evidence that SMEs behave very aggressively and intend to use fintech in running their businesses. The more benefits they feel, the more fintech usage behavior will develop. It is the rational nature of man that what is beneficial to him will encourage him to behave.

Although fintech is considered easy to use, if the benefits are low, SMEs do not intend to use it. Even though there are deviations such as fraud, it does not have an impact on preventing SMEs from using fintech. It is recognized that public awareness of the importance of security has not been a serious consideration, this is because the community has never felt the impact of cyber risk (Chang et al., 2020). Indeed, SMEs are aware of the risks that have a negative impact on the intention of adopting fintech (Smeets \& Zeisberger, 2020), but the problems that arise have not dampened the enthusiasm of SMEs to use fintech.

This study aims to determine whether there has been a transformation of digital financial behavior in Indonesia using fintech by SMEs as the impact of the Covid-19 pandemic and the New Normal era. The benefit of this research is to provide an understanding of SMEs in Indonesia, that in the era of the Covid-19 pandemic and the new normal, the digital economy payment system that uses fintech towards contacless payments is more efficient and provides convenience and smooth running of their business, although risks still need to be considered. Meanwhile, SMEs that still rely on traditional business models tend to find it increasingly difficult to develop.

This research has an interdisciplinary scientific perspective. A person's desire to perform a certain behavior (behavioral intention) is a psychological perspective. Pandemic is a social science perspective that is a new disease spreading across the globe beyond borders (WHO, 2020). Meanwhile, fintech is financial science in collaboration with information technology. In addition to an interdisciplinary scientific perspective, this study also uses an empirical approach, which is to test new normal conditions as a moderating factor for the emergence of new behavioral using fintech. Therefore, this research has an appeal as a research that has novelty from the interdisciplinary aspect of science as well as from the empirical aspect.

\section{HYPOTHESES DEVELOPMENT}

The Covid-19 pandemic has no certainty when it will end, therefore SMEs must be able to properly manage business cycle management using digital transformation (Abdurrahman, 2020;Dubey et al., 2020). The implementation of digital economy through a marketplace carried out by SME entrepreneurs is in accordance with the procedures to have a positive impact amid the Covid-19 pandemic (Kasradze, 2020). According to Wan (2010), SMEs are strongly encouraged to trade in e-commerce, so that they can continue to survive. Large-Scale Social Restrictions (LSSR), limit certain activities in an area that is suspected of being infected with Covid-19. Thus, many activities are carried out at home (Knight \& Wójcik, 2020). Based on the explanation, the following hypothesis is developed.

\section{$H_{1}$. Covid-19/LSSR has a positive effect on Old Behavioral Intention of using fintech.}

The results of research by Gendro \& Kusuma (2020) found before the onset of Covid-19 that Perceived Usefulness (perceived benefits) was proven to have a positive and significant effect on Behavioral Intention of using fintech. The corona pandemic has shifted people's behavior in shopping activities that were previously dominant offline to the online system. Changing patterns are followed by SMEs in order to survive in facing 
the new normal conditions. At least there are several protocol corridors that underlie the digitization of SMEs in preparation for the new normal. Online community activities are inevitable, to prevent the massive spread of Covid-19, either by doing social distancing or physical distancing (Sulistiyo, 2020; Wójcik, 2020). Based on this explanation, the following hypothesis is developed.

\section{$\mathrm{H}_{2}$. Old Behavioral Intention using fintech a positive effect on New Behavioral Intention for using fintech.}

The government issued various policies from the Large-Scale Social Restrictions, to the implementation of the new normal. The implication is that there is a reduction in direct interaction in the center of the crowd. Various sectors were also affected, from large industry players to micro, small and medium enterprises (SMEs). Digital transformation is inevitable in the business world. The modes of communication, work patterns, business consumer behavior patterns are new and shifting. The World Health Organization (WHO) states that Covid-19 will remain in the long term. No one can predict when the pandemic will end. In fact, we hope that the new normal can become a momentum for good opportunities for local business activists to get up and move forward (Juminto, 2020). In addition, the impact of Covid-19 globally has sharply increased the adoption of digital technology in the financial industry. This change in behavior will lead to the phase of The New Normal, which demands that people be able to adapt to these conditions in order to maintain productivity and sustain life (Churry, 2020;Putri Rusadi \& Benuf, 2020). Based on this explanation, the following hypothesis is developed.

\section{$\mathrm{H}_{3}$. New Normal affects the New Behavioral Intention of the use of fintech. \\ $\mathbf{H}_{4}$. New Normal effect on Old Behavioral Intention of using fintech has an impact on New Behavioral Intention of using fintech}

\section{METHOD, DATA, AND ANALYSIS}

The population of this research is SMEs domiciled in Indonesia. The sample used was taken from the SMEs of each province using a purposive sampling method with the following criteria: The SMEs sampled had used fintech to make transactions before the Covid-19 pandemic occurred. The technique of distributing instruments was carried out online to 34 provinces in Indonesia using a questionnaire with an ordinal measurement scale (Likert scale). The results of questionnaires were obtained by SMEs from 19 provinces with a total of 84 SMEs. The number of samples of 84 can be continued referring to the opinion of Hair et al (2019) which states that the minimum number of samples can be continued by using a sample of the number of variables (there are 4) multiplied by 20 , so that the sample used is at least 80 SMEs yang digunakan minimal 80 SMEs.

The indicators for measuring the variables used are as follows.

Table 1. Variable and Indicator

\begin{tabular}{cll}
\hline No & \multicolumn{1}{c}{ Variable } & \multicolumn{1}{c}{ Indicator } \\
\hline 1 & COVID-19/LSSR & The Covid-19 / LSSR impacting SMEs \\
& COVID-19 (coronavirus disease 2019) is a disease & is measured by the following indicators. \\
& caused by a new type of coronavirus, namely & 1. Changing business behavior \\
& Sars-CoV-2, which was first reported in Wuhan & 2. Impact on SMEs businesses \\
China on December 31, 2019 (Lee, 2020). & 3. Livelihoods become stagnant \\
\hline
\end{tabular}




\begin{tabular}{|c|c|c|}
\hline & $\begin{array}{l}\text { Meanwhile the LSSR is a restriction on certain } \\
\text { activities of residents in an area suspected of } \\
\text { being infected with the corona virus to prevent } \\
\text { the possibility of spreading it more widely } \\
\text { (Herliandry et al., 2020) }\end{array}$ & 4. Livelihoods of SMEs to die \\
\hline 2 & $\begin{array}{l}\text { OLD BEHAVIORAL INTENTION (Using } \\
\text { Fintech) } \\
\text { It is the financial behavior of SMEs using fintech } \\
\text { for their business activities before the Covid-19 } \\
\text { pandemic occurred (Aditya \& Wardhana, 2018; } \\
\text { Nursiah, 2017: Putri \& Jumhur, 2019; Bangkara, } \\
\text { Putu, \& Harta, 2016; Gendro \& Kusuma, 2020) }\end{array}$ & $\begin{array}{l}\text { Old behavioral intention using fintech is } \\
\text { measured based on SMEs' perceptions } \\
\text { of these fintech characteristics. } \\
\text { 1. Easy to use of fintech } \\
\text { 2. Can be accessed anywhere and } \\
\text { anytime } \\
\text { 3. The menu is easy to understand } \\
\text { 4. Accurate information } \\
\text { 5. Feel safe } \\
\text { 6. Available when needed } \\
\text { 7. Satisfied using it } \\
\text { 8. Assist in payment transactions } \\
\text { 9. Time is more efficient }\end{array}$ \\
\hline 3 & $\begin{array}{l}\text { NEW NORMAL } \\
\text { It is a new order to adapt to Covid-19, which is a } \\
\text { new habit based on adaptation to cultivate clean } \\
\text { and healthy living habits. This protocol is not } \\
\text { only in the economic sector, but also in education } \\
\text { and religion, so that the addition of positive cases } \\
\text { can be suppressed (Dipna, 2020) }\end{array}$ & $\begin{array}{l}\text { The implementation of the new normal } \\
\text { impact on SMEs is measured using the } \\
\text { following indicators. } \\
\text { 1. Does not interfere SMEs bussines } \\
\text { activities } \\
\text { 2. Still productive if SMEs do } \\
\text { adaptation } \\
\text { 3. Health protocol does not interfere } \\
\text { with business } \\
\text { 4. Does not interfere with the efforts } \\
\text { being made } \\
\text { 5. temporarily closing my workplace } \\
\text { does not interfere with my business } \\
\text { 6. Face-to-face transaction barriers can } \\
\text { be overcome directly by using fintech }\end{array}$ \\
\hline 4 & $\begin{array}{l}\text { NEW BEHAVIORAL INTENTION (Using } \\
\text { Fintech) } \\
\text { It is the intention to behave SMEs using fintech } \\
\text { after the Covid-19 pandemic (Bouey, 2020). In } \\
\text { this era, SMEs are very careful about business } \\
\text { and finance. In order to survive, SMEs must be } \\
\text { ready to adapt to the new normal protocol } \\
\text { (Maritz et al., 2020) }\end{array}$ & $\begin{array}{l}\text { New Behavioral SMEs (using fintech) } \\
\text { after and throughout Covid-19 } \\
\text { pandemic indicators are: } \\
\text { 1. Fintech continues to be used cause } \\
\text { helped SMEs transactions amidst the } \\
\text { Coved-19 Pandemic } \\
\text { 2. In the new normal era, fintech is very } \\
\text { much needed for transactions by } \\
\text { SMEs } \\
\text { 3. To survive, SMEs must adapt to the } \\
\text { new normal by using fintech } \\
\text { 4. To survive, SMEs must adapt to the } \\
\text { new normal and continue to use } \\
\text { fintech for their business transactions }\end{array}$ \\
\hline
\end{tabular}

Before the questionnaire is distributed, it is tested for validity and reliability first. The validity test uses the Pearson bivariate correlation analysis technique, which is significant if the sig. two sides below 0.05. The reliability test used the Cronbach's Alpha method with a significance level of 0.05 (Wiyono, 2020). According to Sekaran \& Bougie (2017), reliability is not good if the alpha value is less than 0.6 , while 0.7 is acceptable and above 0.8 is good. 
In order to determine the quality of the variables, a descriptive analysis was carried out from the results of data collection using a Likert Scale for each variable used. As for inferential analysis, it was carried out with SmartPLS 3.2.9 software through the following stages: (1) testing the validity and reliability of the construct; (2). fit model test, and; (3). Test the hypothesis

\section{RESULTS}

The characteristics of the respondents are as shown in the tables below.

Table 2. Respondent Characteristics

\begin{tabular}{|c|c|c|c|c|}
\hline \multicolumn{5}{|c|}{ Origin Provinces } \\
\hline No & Province & & Amount & $\%$ \\
\hline 1 & DIY & & 16 & 19.05 \\
\hline 2 & Papua & & 2 & 2.38 \\
\hline 3 & Maluku & & 8 & 9.52 \\
\hline 4 & Jawa Tengah & & 12 & 14.29 \\
\hline 5 & Lampung & & 4 & 4.76 \\
\hline 6 & Jambi & & 4 & 4.76 \\
\hline 7 & Bengkulu & & 2 & 2.38 \\
\hline 8 & Riau & & 2 & 2.38 \\
\hline 9 & Sumatera Barat & & 2 & 2.38 \\
\hline 10 & Aceh & & 3 & 3.57 \\
\hline 11 & Sumatera Utara & & 3 & 3.57 \\
\hline 12 & Sumatera Selatan & & 2 & 2.38 \\
\hline 13 & Banten & & 3 & 3.57 \\
\hline 14 & DKI Jakarta & & 4 & 4.76 \\
\hline 15 & Jawa Timur & & 3 & 3.57 \\
\hline 16 & Kalimantan Barat & & 4 & 4.76 \\
\hline 17 & Kalimantan Timur & & 5 & 5.95 \\
\hline 18 & Gorontalo & & 2 & 2.38 \\
\hline 19 & Bali & & 3 & 3.57 \\
\hline & & Total & 84 & 100,00 \\
\hline \multicolumn{5}{|c|}{ Types of Business } \\
\hline No & Business & & Amount & $\%$ \\
\hline 1 & Tourism & & 12 & 14.29 \\
\hline 2 & Transportation & & 6 & 7.14 \\
\hline 3 & Hotel & & 5 & 5.95 \\
\hline 4 & Culinary & & 20 & 23.81 \\
\hline 5 & Souvenir & & 10 & 11.90 \\
\hline 6 & Education & & 8 & 9.52 \\
\hline 7 & Home Production & & 12 & 14.29 \\
\hline \multirow[t]{2}{*}{8} & Store & & 11 & 13.10 \\
\hline & & Total & 84 & 100,00 \\
\hline
\end{tabular}




\begin{tabular}{|c|c|c|c|c|}
\hline \multicolumn{5}{|c|}{ Business Omzet } \\
\hline No & Amount & & Amount & $\%$ \\
\hline 1 & Maximum 300 jt/Tahun & & 70 & 83.33 \\
\hline \multirow[t]{2}{*}{2} & Rp.300 jt - Rp.2,5 Milyar & & 14 & 16.67 \\
\hline & & Total & 84 & 100,00 \\
\hline \multicolumn{5}{|c|}{ Total Assets } \\
\hline No & Assets & & Amount & $\%$ \\
\hline 1 & Maximum Rp.50 jt & & 40 & 47.62 \\
\hline 2 & Rp. 50 jt - Rp. 500 jt & & 30 & 35.71 \\
\hline \multirow[t]{2}{*}{3} & Diatas Rp. 500 jt & & 14 & 16.67 \\
\hline & & Total & 84 & 100,00 \\
\hline
\end{tabular}

Based on the table 2 above, the respondents who gave the highest response were from Yogyakarta $19.05 \%$ and Central Java $14.29 \%$. As for the highest respondent's type of business was culinary $23.81 \%$ followed by tourism and home production businesses $14.29 \%$. Meanwhile, the respondent's income is up to Rp. 300 million is $83.33 \%$, and Rp. 300 million - Rp. 2.5 billion is $16.67 \%$, while the amount of respondent's assets is up to Rp. 50 million is $47.62 \%$, Rp. 50 million - Rp. 500 million is $35.71 \%$, and above Rp. 500 million is $16.67 \%$.

The fintech used by SMEs is as follows:

Table 3.The fintech used by respondents

\begin{tabular}{|c|c|c|c|c|c|}
\hline \multirow[t]{2}{*}{ No } & \multirow[t]{2}{*}{ Fintech } & \multicolumn{2}{|c|}{$\begin{array}{l}\text { Old Behavioral } \\
\text { Intention } \\
\text { (Use of Fintech) }\end{array}$} & \multicolumn{2}{|c|}{$\begin{array}{l}\text { New Behavioral } \\
\text { Intention } \\
\text { (Use of Fintech) }\end{array}$} \\
\hline & & Amount & $\%$ & Amount & $\%$ \\
\hline 1 & Gopay & 21 & 25.00 & 26 & 30.95 \\
\hline 2 & Ovo & 15 & 17.86 & 16 & 19.05 \\
\hline 3 & Doku & 7 & 8.33 & 7 & 8.33 \\
\hline 4 & Dana & 9 & 10.71 & 11 & 13.10 \\
\hline 5 & T-Cash & 8 & 9.52 & 8 & 9.52 \\
\hline 6 & Online Pajak & 6 & 7.14 & 4 & 4.76 \\
\hline 7 & Kitabisa & 3 & 3.57 & 2 & 2.38 \\
\hline 8 & Other & 8 & 9.52 & 8 & 9.52 \\
\hline 9 & No use & 7 & 8.33 & 2 & 2.38 \\
\hline & Total & 84 & 100,00 & 84 & 100,00 \\
\hline
\end{tabular}

Source: Processed data

Based on the table above, the most widely used fintech applications by respondents before and after the Pandemic were Gopay (25\% - 30.95\%), OVO (17.86\% - 19.05\%), and DANA $(10.71 \%-13,10 \%)$. From the data above, it can be seen that there is an increase in usage of fintech, from 7 SMEs that did not use to 2 SMEs did not use on new behavioral intention using fintech. 


\section{Instrument Test}

The results of the research instrument test for each variable used SPSS ver.25 software as shown in the table below.

\section{Variable of Covid-19/LSSR}

The test results are as follows:

Table 4. Test the Validity and Reliability of the Covid-19/LSSR Variables

\begin{tabular}{cccc}
\hline Point & Pearson & Sig & Status \\
\hline X1 & 0.796 & 0.000 & Valid \\
X2 & 0.817 & 0.000 & Valid \\
X3 & 0.923 & 0.000 & Valid \\
X4 & 0.703 & 0.000 & Valid \\
\hline Score cronchach's alpha 0,811 are reliabel. & &
\end{tabular}

Score croncbach's alpha 0,811 are reliabel.

Source: SPSS output

Based on the table above, 4 question items on the Covid-19 variable have a significance smaller than 0.05 , so all question items are declared valid. Croncbach's alpha value of 0.811 is greater than 0.7 so that the questions on the Covid-19 variable can also be declared reliable (Wiyono, 2020).

\section{Variable of Old Behavioral Intention}

The test results are as follows:

Table 5. Test the Validity and Reliability of Old Behavioral Intention (Use of Fintech) Variables

\begin{tabular}{cccc}
\hline Point & $\begin{array}{c}\text { Pearson } \\
\text { Correlation }\end{array}$ & Sig & Status \\
\hline Y1.1 & 0.799 & 0.000 & Valid \\
Y1.2 & 0.902 & 0.000 & Valid \\
Y1.3 & 0.904 & 0.000 & Valid \\
Y1.4 & 0.900 & 0.000 & Valid \\
Y1.5 & 0.862 & 0.000 & Valid \\
Y1.6 & 0.945 & 0.000 & Valid \\
Y1.7 & 0.946 & 0.000 & Valid \\
Y1.8 & 0.934 & 0.000 & Valid \\
Y1.9 & 0.911 & 0.000 & Valid \\
\hline
\end{tabular}

Score croncbach's alpha 0,970 are reliabel.

Source: SPSS output

Based on the table above, 9 question items on the Old Behavioral Intention (Use of Fintech) variable have a significance less than 0.05 , so all question items are declared valid. The Croncbach's alpha value of 0.970 is greater than 0.7 so that the questions on the Old Behavioral Intention (Use of Fintech) variable can also be declared reliable (Wiyono, 2020).

\section{Variable of New Normal}

The test results are as follows:

Table 6. Test the validity and reliability of the New Normal variable

\begin{tabular}{cccc}
\hline Point & $\begin{array}{c}\text { Pearson } \\
\text { Correlation }\end{array}$ & Sig & Status \\
\hline Z1 & 0.735 & 0.000 & Valid \\
Z2 & 0.604 & 0.000 & Valid \\
\hline
\end{tabular}




\begin{tabular}{cccc}
\hline Z3 & 0.619 & 0.000 & Valid \\
Z4 & 0.772 & 0.000 & Valid \\
Z5 & 0.522 & 0.000 & Valid \\
Z6 & 0.559 & 0.000 & Valid \\
\hline
\end{tabular}

Score croncbach's alpha 0.852 are reliabel.

Source: SPSS output

Based on the table above, the 6 item questions on the New Normal variable have a significance smaller than 0.05 , so all question items are declared valid. The Croncbach's alpha value of 0.852 is greater than 0.7 , so that the questions on the service variable can also be declared reliable (Wiyono, 2020).

\section{Variable of New Behavioral Intention (Use of Fintech)}

The test results are as follows:

Table 7. Validity and Reliability Test of New Behavioral Intention (Use of Fintech)

\begin{tabular}{cccc}
\hline Point & $\begin{array}{c}\text { Pearson } \\
\text { Correlation }\end{array}$ & Sig & Status \\
\hline Y2.1 & 0.843 & 0.000 & Valid \\
Y2.2 & 0.831 & 0.000 & Valid \\
Y2.3 & 0.750 & 0.000 & Valid \\
Y2.4 & 0.797 & 0.000 & Valid \\
\hline
\end{tabular}

Score croncbach's alpha 0.852 are reliabel.

Source: SPSS output

Based on the table above, the 4 question items on the New Behavioral Intention (Use of Fintech) variable have a significance smaller than 0.05 , so all question items are declared valid. The croncbach's alpha value of 0.852 is greater than 0.7 so that the questions on the service variable can also be declared reliable (Wiyono, 2020).

\section{Descriptive Analysis}

The results of data processing are descriptions of each variable as in the following tables. ( $\mathrm{TD}=$ Totally Disagree; $\mathrm{D}=$ Disagree; $\mathrm{N}=$ Neutral; $\mathrm{A}=$ Agree; $\mathrm{TA}=$ Totally Agree)

\section{Variable of Covid-19/LSSR (Large-Scale Social Restrictions)}

Table 8. Partial Descriptions of Covid-19 / LSSR Variable

\begin{tabular}{|c|c|c|c|c|c|c|c|c|c|c|c|}
\hline \multirow{2}{*}{ No } & \multirow{2}{*}{$\begin{array}{l}\text { Questionnaire } \\
\text { Item }\end{array}$} & \multicolumn{2}{|c|}{ TD } & \multicolumn{2}{|c|}{$\mathrm{D}$} & \multicolumn{2}{|c|}{$\mathrm{N}$} & \multicolumn{2}{|c|}{ A } & \multicolumn{2}{|c|}{ TA } \\
\hline & & $\mathrm{F}$ & $\%$ & F & $\%$ & $\mathrm{~F}$ & $\%$ & $\mathrm{~F}$ & $\%$ & $\mathrm{~F}$ & $\%$ \\
\hline 1 & $\begin{array}{l}\text { The COVID-19 pandemic } \\
\text { has transformed the SME } \\
\text { business }\end{array}$ & 4 & 4.76 & 2 & 2.38 & 10 & 11.90 & 16 & 19.05 & 52 & 61.90 \\
\hline 2 & $\begin{array}{l}\text { The government's policy } \\
\text { to impose LSSR has an } \\
\text { impact on SME } \\
\text { businesses }\end{array}$ & 2 & 2.38 & 2 & 2.38 & 8 & 9.52 & 12 & 14.29 & 60 & 71.43 \\
\hline 3 & $\begin{array}{l}\text { LSSR causes the } \\
\text { livelihoods of SMES to } \\
\text { become stagnant }\end{array}$ & 4 & 4.76 & 8 & 9.52 & 8 & 9.52 & 14 & 16.67 & 50 & 59.52 \\
\hline 4 & $\begin{array}{l}\text { LSSR causes the } \\
\text { livelihoods of SMES to } \\
\text { die }\end{array}$ & 8 & 9.52 & 12 & 14.29 & 14 & 16.67 & 16 & 19.05 & 34 & 40.48 \\
\hline
\end{tabular}


Sources: Processed data

Note :

(TD=Totally Disagree; $\mathrm{D}=$ Disagree; $\mathrm{N}=$ Neutral; $\mathrm{A}=$ Agree; $\mathrm{TA}=$ Totally Agree)

Based on the table above, the perception of respondents who indicated that the answers strongly agreed with a prominent percentage of the questionnaire proposed gave an indication that the following conclusions could be drawn: (1). Government policies to impose LSSR " Totally Agree " had an impact on SMEs (71.43\%); (2). The COVID-19 pandemic has changed the SME business "Totally Agree" (61.90\%); (3) .LSSR causes the livelihoods of SMES to become stagnant "Totally Agree " (59.52\%).

\section{Variable of Old Behavioral Intention (Use of Fintech)}

Table 9. Partial Description of Old Behavioral Intention (Use of Fintech) Variable

\begin{tabular}{|c|c|c|c|c|c|c|c|c|c|c|c|}
\hline \multirow{2}{*}{ No } & \multirow{2}{*}{$\begin{array}{l}\text { Questionnaire } \\
\text { Item }\end{array}$} & \multicolumn{2}{|c|}{ TD } & \multicolumn{2}{|c|}{$\mathrm{D}$} & \multicolumn{2}{|c|}{$\mathrm{N}$} & \multicolumn{2}{|c|}{ A } & \multicolumn{2}{|c|}{ TA } \\
\hline & & $\mathbf{F}$ & $\%$ & $\mathbf{F}$ & $\%$ & $\mathbf{F}$ & $\%$ & $\mathbf{F}$ & $\%$ & $\mathbf{F}$ & $\%$ \\
\hline 1 & $\begin{array}{l}\text { I easily make transactions } \\
\text { using fintech }\end{array}$ & 4 & 4.76 & 14 & 16.67 & 16 & 19.05 & 16 & 19.05 & 34 & 40.48 \\
\hline 2 & $\begin{array}{l}\text { Fintech can be accessed } \\
\text { anytime and anywhere }\end{array}$ & 2 & 2.38 & 12 & 14.29 & 14 & 16.67 & 14 & 16.67 & 42 & 50.00 \\
\hline 3 & $\begin{array}{l}\text { The fintech menu is easy to } \\
\text { understand }\end{array}$ & 4 & 4.76 & 4 & 4.76 & 24 & 28.57 & 22 & 26.19 & 30 & 35.71 \\
\hline 4 & $\begin{array}{l}\text { Fintech information is very } \\
\text { accurate }\end{array}$ & 2 & 2.38 & 6 & 7.14 & 36 & 42.86 & 22 & 26.19 & 18 & 21.43 \\
\hline 5 & I feel safe using fintech & 2 & 2.38 & 8 & 9.52 & 30 & 35.71 & 24 & 28.57 & 20 & 23.81 \\
\hline 6 & $\begin{array}{l}\text { Fintech service is always } \\
\text { available when I need it }\end{array}$ & 2 & 2.38 & 8 & 9.52 & 26 & 30.95 & 16 & 19.05 & 32 & 38.10 \\
\hline 7 & I feel satisfied using fintech & 2 & 2.38 & 10 & 11.90 & 24 & 28.57 & 20 & 23.81 & 28 & 33.33 \\
\hline 8 & $\begin{array}{l}\text { Fintech helps me with } \\
\text { payment transactions }\end{array}$ & 2 & 2.38 & 10 & 11.90 & 18 & 21.43 & 22 & 26.19 & 32 & 38.10 \\
\hline 9 & $\begin{array}{l}\text { My time is more efficient } \\
\text { using fintech }\end{array}$ & 2 & 2.38 & 10 & 11.90 & 20 & 23.81 & 16 & 19.05 & 36 & 42.86 \\
\hline
\end{tabular}

Based on the table above, the respondent's perception that the answers Totally Agreewith the prominent percentage of the questionnaire proposed provides an indication that the following conclusions can be drawn: (1).Fintech can be accessed at any time and wherever it is "Totally Agree" (50\%); (2). more time efficient using fintech "Totally Agree" (42.86\%); (3). Fintech is easy to use to make transactions "Totally Agree" $(40.48 \%)$; (4). Fintech services are always available when I need "'Totally Agree" (38.10\%); (5) .Fintech assists in payment transactions "Totally Agree" (38.10\%).

\section{Variable of New Normal}

Table 10. Partial Description of New Normal Variable

\begin{tabular}{|c|c|c|c|c|c|c|c|c|c|c|c|}
\hline \multirow{2}{*}{ No } & \multirow{2}{*}{$\begin{array}{c}\text { Questionnaire } \\
\text { Item }\end{array}$} & \multicolumn{2}{|c|}{ TD } & \multicolumn{2}{|r|}{$\mathrm{D}$} & \multicolumn{2}{|c|}{$\mathrm{N}$} & \multicolumn{2}{|c|}{$\mathrm{A}$} & \multicolumn{2}{|c|}{ TA } \\
\hline & & $\mathbf{F}$ & $\%$ & $\mathbf{F}$ & $\%$ & $\mathbf{F}$ & $\%$ & $\mathbf{F}$ & $\%$ & $F$ & $\%$ \\
\hline 1 & $\begin{array}{l}\text { New normal doesn't } \\
\text { interfere with my } \\
\text { business }\end{array}$ & 14 & 16.67 & 10 & 11.90 & 20 & 23.81 & 18 & 21.43 & 22 & 26.19 \\
\hline
\end{tabular}




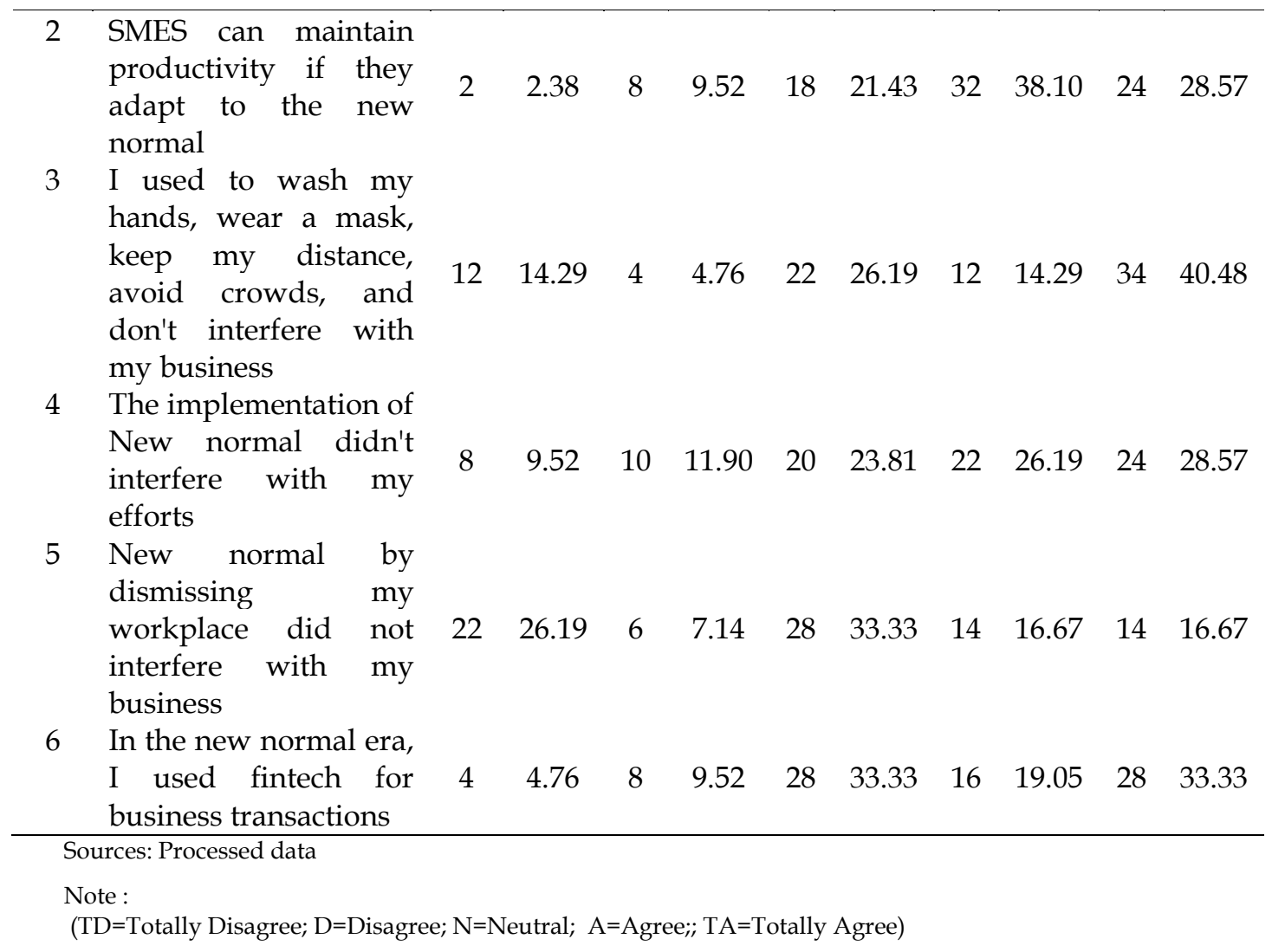

Based on the table above, the respondents' perceptions who indicated that the answers strongly agreed with the prominent percentage of the questionnaire proposed gave an indication that the following conclusions could be drawn: (1) get used to washing hands, wear masks, keep your distance, avoid crowds, do not interfere with your business. "Totally Agree" (40,48\%); (2). In the new normal era, SMEs use fintech for business transactions "Totally Agree" (33.33\%); (3). SMES can maintain productivity if they adapt to the new normal "Totally Agree" (28.57\%).

Variable of New Behavioral Intention (Use of Fintech)

Table 11. Partial Description of New Behavioral Intention (Use of Fintech) Variable

\begin{tabular}{|c|c|c|c|c|c|c|c|c|c|c|c|}
\hline \multirow{2}{*}{ No } & \multirow{2}{*}{$\begin{array}{l}\text { Questionnaire } \\
\text { Item }\end{array}$} & \multicolumn{2}{|c|}{ TD } & \multicolumn{2}{|c|}{$\mathrm{D}$} & \multicolumn{2}{|c|}{$\mathrm{N}$} & \multicolumn{2}{|c|}{ A } & \multicolumn{2}{|c|}{ TA } \\
\hline & & F & $\%$ & $F$ & $\%$ & $F$ & $\%$ & $\mathbf{F}$ & $\%$ & $F$ & $\%$ \\
\hline 1 & $\begin{array}{l}\text { Fintech helped me with } \\
\text { transactions amidst the } \\
\text { Coved-19 Pandemic }\end{array}$ & 2 & 2.38 & 12 & 14.29 & 24 & 28.57 & 12 & 14.29 & 34 & 40.48 \\
\hline 2 & $\begin{array}{l}\text { In the new normal era, the } \\
\text { use of fintech is very } \\
\text { much needed for SME } \\
\text { transactions }\end{array}$ & 2 & 2.38 & 8 & 9.52 & 28 & 33.33 & 14 & 16.67 & 32 & 38.10 \\
\hline 3 & $\begin{array}{l}\text { In order to survive, SMEs } \\
\text { must adapt to the new } \\
\text { normal }\end{array}$ & 0 & 0.00 & 6 & 7.14 & 4 & 4.76 & 20 & 23.81 & 54 & 64.29 \\
\hline 4 & $\begin{array}{l}\text { By applying digital } \\
\text { technology, SMEs are able } \\
\text { to survive the new normal }\end{array}$ & 2 & 2.38 & 2 & 2.38 & 14 & 16.67 & 22 & 26.19 & 44 & 52.38 \\
\hline
\end{tabular}

Sources: Processed data

Note :

(TD=Totally Disagree; $\mathrm{D}=$ Disagree; $\mathrm{N}=$ Neutral; A=Agree; $\mathrm{TA}=$ Totally Agree) 
Based on the table above, the perception of respondents who indicated that the answers strongly agreed with the prominent percentage of the questionnaire proposed gave an indication that the following conclusions could be drawn: (1). In order to survive, SMEs must adapt to the new normal "'Totally Agree" (64.29\%); (2). By applying digital technology, SMEs are able to survive the new normal "Totally Agree" (52.38\%); (3). Fintech helps SMEs transactions amid the Covid-19 Pandemic "Totally Agree" (40.48\%).

\section{Confirmatory Factor Analysis}

Confirmatory Factor Analysis includes testing of: Convergence Validity, Discriminant Validity, and Composite Reliability with the following results. The initial model of this study prior to confirmatory factor analysis is shown in the following figure.

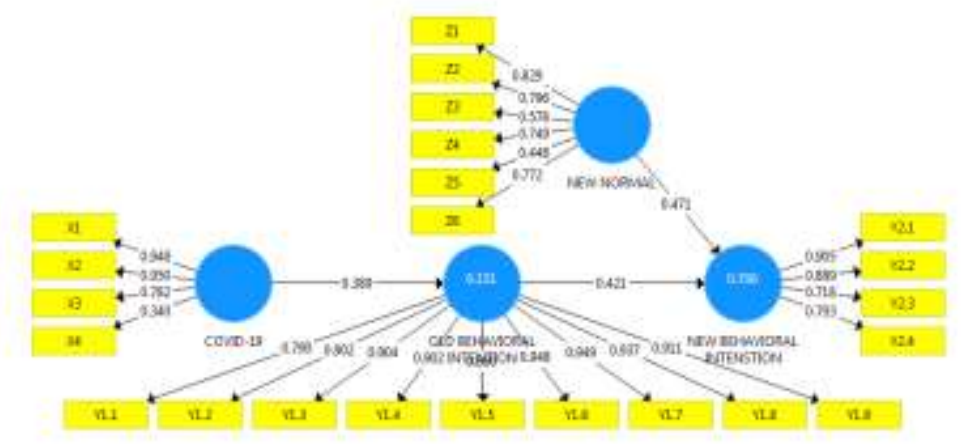

Figure 1. Models Before the CFA Test

\section{Convergent Validity}

The results of the convergent validity test are as shown in the table below.

Table 12. Convergent Validity

\begin{tabular}{|c|c|c|c|c|c|}
\hline Indicators & $\begin{array}{l}\text { Covid-19 } \\
(X)\end{array}$ & $\begin{array}{c}\text { Old } \\
\text { Behavioral } \\
\text { (Y1) }\end{array}$ & $\begin{array}{l}\text { New } \\
\text { Normal } \\
\text { (Z) }\end{array}$ & $\begin{array}{c}\text { New Behavioral } \\
\text { (Y2) }\end{array}$ & Status \\
\hline $\mathrm{X} 1$ & 0,948 & & & & Accepted \\
\hline $\mathrm{X} 2$ & 0,950 & & & & Accepted \\
\hline X3 & 0,782 & & & & Accepted \\
\hline X4 & 0,340 & & & & not accepted \\
\hline Y1.1 & & 0,790 & & & Accepted \\
\hline Y1.2 & & 0,907 & & & Accepted \\
\hline Y1.3 & & 0,904 & & & Accepted \\
\hline Y1.4 & & 0,860 & & & Accepted \\
\hline Y1.5 & & 0,948 & & & Accepted \\
\hline Y1.6 & & 0,949 & & & Accepted \\
\hline Y1.7 & & 0,949 & & & Accepted \\
\hline Y1.8 & & 0,937 & & & Accepted \\
\hline Y1.9 & & 0,911 & & & Accepted \\
\hline Z1 & & & 0,829 & & Accepted \\
\hline Z2 & & & 0,796 & & Accepted \\
\hline Z3 & & & 0,578 & & Accepted \\
\hline Z4 & & & 0,749 & & Accepted \\
\hline Z5 & & & 0,448 & & not accepted \\
\hline Z6 & & & 0,772 & & Accepted \\
\hline Y2.1 & & & & 0,905 & Accepted \\
\hline
\end{tabular}




\begin{tabular}{lll}
\hline Y2.2 & 0,889 & Accepted \\
Y2.3 & $\mathbf{0 , 7 1 8}$ & Accepted \\
Y2.4 & $\mathbf{0 , 7 9 3}$ & Accepted \\
\hline
\end{tabular}

Source: SmatPLS output

Based on the table above, the convergent validity test shows that there are two invalid indicators, namely: X4 and Z5, with a loading value of $<0.7$ (Wiyono, 2020).

Discriminant Validity

The results of the discriminat validity test are as shown in the table below.

Table 13.Discriminant Validity

\begin{tabular}{cccccc}
\hline Indicators & $\begin{array}{c}\text { Covid- } \\
\mathbf{1 9 / L S S R} \\
\mathbf{( X )}\end{array}$ & $\begin{array}{c}\text { Old } \\
\text { Behavioral } \\
\mathbf{( Y 1} \mathbf{1}\end{array}$ & $\begin{array}{c}\text { New } \\
\text { Normal } \\
\mathbf{( Z )}\end{array}$ & $\begin{array}{c}\text { New } \\
\text { Behavioral } \\
\mathbf{( Y 2 )}\end{array}$ & Status \\
\hline X1 & $\mathbf{0 , 9 4 8}$ & 0,436 & 0,278 & 0,456 & Accepted \\
X2 & $\mathbf{0 , 9 5 0}$ & 0,356 & 0,273 & 0,400 & Accepted \\
X3 & $\mathbf{0 , 7 8 2}$ & 0,160 & $-0,030$ & 0,144 & Accepted \\
X4 & $\mathbf{0 , 3 4 0}$ & $\mathbf{0 , 0 1 6}$ & $-0,293$ & $-0,181$ & Accepted \\
Y1.1 & 0,475 & $\mathbf{0 , 7 9 0}$ & 0,610 & 0,608 & Accepted \\
Y1.2 & 0,477 & $\mathbf{0 , 9 0 7}$ & 0,656 & 0,751 & Accepted \\
Y1.3 & 0,401 & $\mathbf{0 , 9 0 4}$ & 0,662 & 0,684 & Accepted \\
Y1.4 & 0,314 & $\mathbf{0 , 8 6 0}$ & 0,692 & 0,671 & Accepted \\
Y1.5 & 0,234 & $\mathbf{0 , 9 4 8}$ & 0,593 & 0,588 & Accepted \\
Y1.6 & 0,287 & $\mathbf{0 , 9 4 9}$ & 0,776 & 0,795 & Accepted \\
Y1.7 & 0,345 & $\mathbf{0 , 9 4 9}$ & 0,770 & 0,793 & Accepted \\
Y1.8 & 0,278 & $\mathbf{0 , 9 3 7}$ & 0,699 & 0,702 & Accepted \\
Y1.9 & 0,312 & $\mathbf{0 , 9 1 1}$ & 0,791 & 0,737 & Accepted \\
Z1 & 0,058 & 0,500 & $\mathbf{0 , 8 2 9}$ & 0,517 & Accepted \\
Z2 & 0,341 & 0,579 & $\mathbf{0 , 7 9 6}$ & 0,698 & Accepted \\
Z3 & 0,133 & 0,399 & $\mathbf{0 , 5 7 8}$ & 0,334 & Accepted \\
Z4 & 0,050 & 0,365 & $\mathbf{0 , 7 4 9}$ & 0,403 & Accepted \\
Z5 & $-0,108$ & 0,157 & $\mathbf{0 , 4 4 8}$ & 0,281 & Accepted \\
Z6 & 0,276 & 0,613 & $\mathbf{0 , 7 7 2}$ & 0,623 & Accepted \\
Y2.1 & 0,385 & 0,863 & 0,741 & $\mathbf{0 , 9 0 5}$ & Accepted \\
Y2.2 & 0,236 & 0,807 & 0,676 & $\mathbf{0 , 8 8 9}$ & Accepted \\
Y2.3 & 0,398 & 0,352 & 0,525 & $\mathbf{0 , 7 1 8}$ & Accepted \\
Y2.4 & 0,389 & 0,434 & 0,675 & $\mathbf{0 , 7 9 3}$ & Accepted \\
\hline
\end{tabular}

Source: SmatPLS output

The discriminant validity test shows that all indicators are accepted, namely: with the results of cross loading the indicators have a higher correlation with the origin variable compared to other variables (Wiyono, 2020).

\section{Composite Reliability}

The results of the composite reliability test are as shown in the table below.

Table 14. Composite Reliability

\begin{tabular}{lcc}
\multicolumn{1}{c}{ Variable } & $\begin{array}{c}\text { Composit } \\
\text { Reliability }\end{array}$ & Quality \\
\hline Covid-19/LSSR (X) & 0,861 & Reliabel \\
Old Behavioral (Y1) & 0,898 & Reliabel \\
New Normal (Z) & 0,853 & Reliabel \\
New Behavioral (Y2) & 0,975 & Reliabel \\
\hline
\end{tabular}

Source: SmatPLS 
Based on the table above, all constructs are declared reliable as indicated by the composite reliability value $>0.70$ (Wiyono, 2020).

\section{Model Fit Test}

After the confirmatory factor analysis test, some invalid indicators were removed so that the model image looks like the one below.

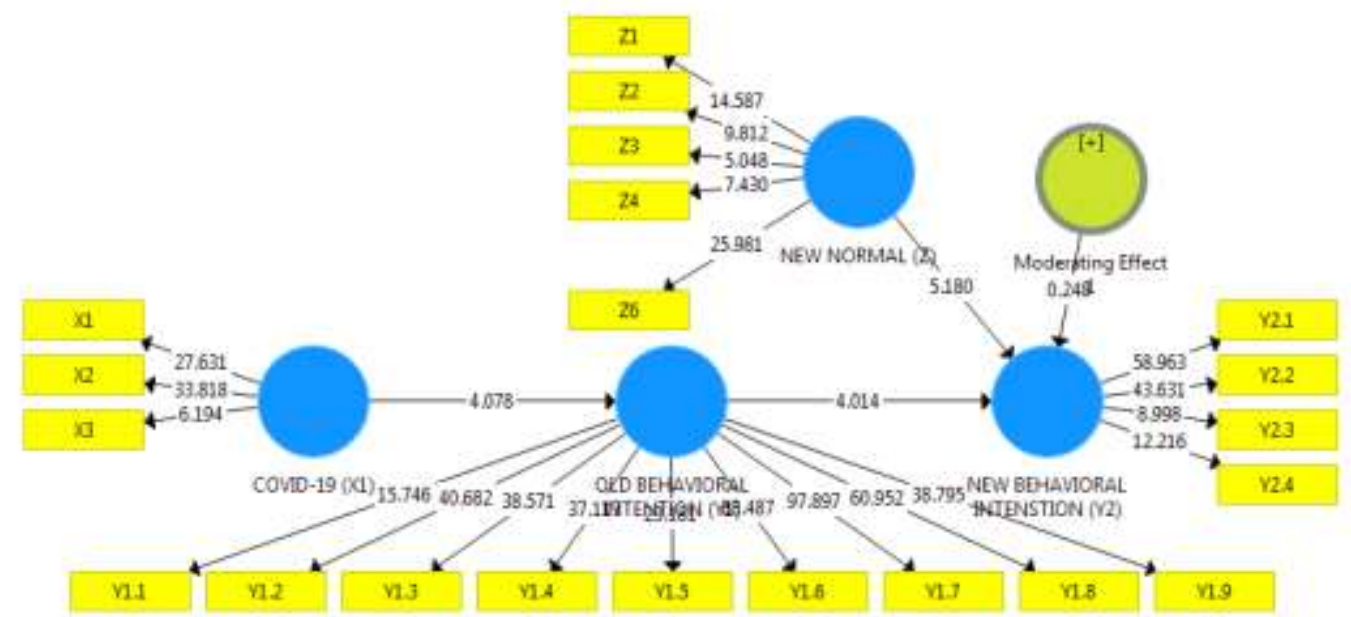

Figure 2. Model After CFA Test

The results of testing the fit model are as in the following table

Table 15. Model Fit Test

\begin{tabular}{lccc}
\multicolumn{1}{c}{ Fit Summary } & Estimated & Cut Value & Status \\
\hline SRMR & 0,134 & $<0,10$ & Moderate \\
Chi-Square & 925,51 & $<\chi^{2}$ Tabel $(522,07)$ & Not good \\
NFI & 0,623 & Mendekati 1 & Moderate \\
Rms Theta & 0,235 & $<0,12$ & Not good \\
\hline
\end{tabular}

Source: SmatPLS output

Standardized Root Mean Square Residual (SRMR) is a measure of the absolute value of the mean residual covariance. Values less than 0.10 are considered appropriate (Dijkstra \& Henseler, 2017) which is a goodness of fit measure for PLS-SEM which can be used to avoid misspecification models. The test results with SRMR $=0.134$ indicate that the model is moderate. Chi-Square testing resulted in $X 2$ Statistics (925.51)> $X 2$ Table (552.075), meaning that the number of manifest variables in the PLS path model and the number of independent variables in the covariance matrix model were insufficient (Table values obtained from DF $=499$ with $a=0,05)$. The Normed Fit Index (NFI) is a measure of conformity. The bigger the NFI result, the better the model. The NFI test result $=0.623$ shows moderate results. Furthermore, The root mean squared residual covariance matrix of the outer model residuals (RMS _theta) assesses the extent to which outer model residues are correlated. Size must be close to zero to show a good model. An RMS_theta value below 0.12 indicates a suitable model ((Dijkstra \& Henseler, 2015)). The test results of rms Theta $=0.235$ indicate that the model is not good. 


\section{Hypothesis testing}

The results of hypothesis testing are shown in table as follows:

Tabel 16. Hypothesis Test Results

\begin{tabular}{clcccc}
\hline \multicolumn{1}{c}{ Hipotesis } & $\begin{array}{c}\text { Original } \\
\text { Sample }\end{array}$ & $\boldsymbol{P}_{\text {Value }}$ & Status \\
\hline H1 & $\begin{array}{l}\text { Covid-19/LSSR affects Old Behavioral } \\
\text { Intention of using fintech } \\
\text { Old Behavioral Intention affects the New } \\
\text { Behavioral Intention of using fintech }\end{array}$ & 0.391 & 0.000 & Accepted \\
H3. $\begin{array}{l}\text { New Normal affects the New Behavioral } \\
\text { Intention of using fintech }\end{array}$ & 0.480 & 0.000 & Accepted \\
$\begin{array}{l}\text { New Normal effect on Old Behavioral } \\
\text { Intention of using fintech has an impact on } \\
\text { New Behavioral Intention of using fintech }\end{array}$ & -0.017 & 0.788 & Not accepted \\
\hline Source: SmatPLS output
\end{tabular}

H1. Covid-19/LSSR has a positive and significant effect on Old Behavioral Intention of using fintech, as evidenced by the original sample 0.391 and Pvalue $0.000<\alpha$ $=0.05$. The Covid-19 pandemic has no certainty when it will end, therefore SMEs must be able to properly manage business cycle management using digital transformation (Abdurrahman, 2020). The implementation of digital economy through a marketplace carried out by SME entrepreneurs has had a positive impact amid the Covid-19 pandemic. According to Wan (2010), SMEs are strongly encouraged to trade in ecommerce, so that they can continue to survive. Large-Scale Social Restrictions (LSSR) restrict certain activities in an area that is suspected of being infected with Covid-19. Based on this explanation, Covid-19 and LSSR have a significant influence on Old Behavioral Intention of using fintech.

H2. Old Behavioral Intention of using fintech is proven to have a positive and significant effect on New Behavioral Intention of using fintech, as evidenced by the original sample 0.336 and Pvalue $0.000<\alpha=0.05$. The results of research by Gendro \& Kusuma (2020) found before the occurrence of Covid-19 that Perceived Usefulness of using fintech was proven to have a positive and significant effect on Behavioral Intention of using fintech. The Covid-19 pandemic has shifted people's behavior in shopping activities that were previously dominant offline to the online system. Changing patterns are followed by SMEs in order to survive in facing the new normal conditions. At least there are several protocol corridors that underlie the digitization of SMEs in preparation for the new normal. Online transaction activities are inevitable, to prevent the massive spread of Covid-19, either by doing social distancing or physical distancing (Sulistiyo, 2020). Based on these conditions, the behavior of SMEs using fintech before the Covid-19 Pandemic remains a habit that has occurred after the Covid-19 Pandemic.

H3. New Normal has a positive and significant effect on New Behavioral Intention of using fintech, as evidenced by the original sample 0.480 and Pvalue $0.000<\alpha$ $=0.05$. The government issued various policies from the LSRR to the implementation of the new normal. The implication is that there is a reduction in direct interaction in the center of the crowd. Various sectors were also affected, from large industry to micro, small and medium enterprises (SMEs). Digital transformation is inevitable in the business world. The modes of communication, work patterns, business consumer behavior patterns are new and shifting. The World Health Organization (WHO) states that Covid- 
19 will remain in the long term. No one can predict when the pandemic will end. In fact, we hope that the new normal can become a momentum for good opportunities for local business activists to get up and move forward (Juminto, 2020). In addition, the impact of Covid-19 globally has sharply increased the adoption of digital technology in the financial industry. This change in behavior will lead to the The New Normal phase, which demands that people be able to adapt to these conditions in order to maintain productivity and sustain life (Churry, 2020). Based on these conditions, the new normal has a positive and significant effect on the new behavioral intention of using technology because, among other things, there is a reduction in direct interaction in the center of the crowd so that digital transformation is inevitable in the business world.

H4. The effect of New Normal on Old Behavioral Intention of using fintech is not proven to have a moderating effect on New Behavioral Intention of using fintech, as evidenced by the original sample -0017 and Pvalue 0.788 $\alpha=0.05$. Referring to the results of research by Gendro \& Kusuma (2020), it was found that before the Covid-19 Perceived Usefulness of using fintech had been proven to have a positive and significant effect on Behavioral Intention of the use of fintech. SMEs have already felt the benefits of using fintech for their business activities. On the other hand, the use of finteh in the era of the Covid-19 pandemic and the new normal is also required to reduce direct interaction in the center of the crowd so that digital transformation is inevitable in the business world. Based on this explanation, the new normal variable is no longer able to moderate because SMEs are accustomed to carrying out their activities using fintech.

\section{DISCUSSION}

Based on the Hypothesis Test Results table, Covid-19/LSSR has a positive and significant effect on Old Behavioral Intention of using fintech. These results are in line with research Abdurrahman (2020) which states that the Covid-19 pandemic has no certainty when it will end, therefore SMEs must be able to properly manage business cycle management using digital transformation The implementation of digital economy through a marketplace carried out by SME entrepreneurs is in accordance with the procedures to have a positive impact amid the Covid-19 pandemic. So were the findings Wan (2010), SMEs are strongly encouraged to trade in e-commerce, so that they can continue to survive. Large-Scale Social Restrictions (LSSR) limit certain activities in an area that is suspected of being infected with Covid-19. Thus, many activities are carried out at home.

Based on the Hypothesis Test Results table, Old Behavioral Intention of using fintech is proven to have a positive and significant effect on New Behavioral Intention of using fintech. The results are in line with research by Gendro \& Kusuma (2020) found before the onset of Covid-19/LSSR that Perceived Usefulness (perceived benefits) was proven to have a positive and significant effect on Behavioral Intention of using fintech. The corona pandemic has shifted people's behavior in shopping activities that were previously dominant offline to the online system. Changing patterns are followed by SMES players in order to survive in facing the new normal conditions. At least there are several protocol corridors that underlie the digitization of SMEs in preparation for the new normal. Online community activities are inevitable, to prevent the massive spread of Covid-19, either by doing social distancing or physical distancing (Sulistiyo, 2020). 
Based on the Hypothesis Test Results table, New Normal has a positive and significant effect on New Behavioral Intention of using fintech. The results are in line with The government issued various policies from the LSSR to the implementation of the new normal. The implication is that there is a reduction in direct interaction in the center of the crowd. Various sectors were also affected, from large industry players to micro, small and medium enterprises (SMEs). Digital transformation is inevitable in the business world. The modes of communication, work patterns, business consumer behavior patterns are new and shifting. The World Health Organization (WHO) states that Covid-19 will remain in the long term. No one can predict when the pandemic will end. In fact, we hope that the new normal can become a momentum for good opportunities for local business activists to get up and move forward (Juminto, 2020). In addition, the impact of Covid-19 globally has sharply increased the adoption of digital technology in the financial industry. This change in behavior will lead to the phase of The New Normal, which demands that people be able to adapt to these conditions in order to maintain productivity and sustain life (Churry, 2020). Based on this explanation, the following hypothesis is developed.

Based on the Hypothesis Test Results table, The effect of New Normal on Old Behavioral Intention of using fintech is not proven to have a moderating effect on New Behavioral Intention of using fintech. SMEs in the new normal era lay in integration, such as integration of payment systems using fintech. Of course, this integration can be used immediately if you join the marketplace, and SMEs have already gained experience of getting the benefits of using fintech before the Covid-19 pandemic, so that new normal conditions do not have a significant effect on increasing use of fintech. The benefits felt by SMEs by implementing the digital economy. The impact of the use of fintech that has been felt by SMEs is that they can sell their products to a wider market (Yan, 2015; Ahlstrom et al., 2020; Ratna et al., 2020).

\section{CONCLUSION}

Covid-19 / LSSR has a positive and significant effect on Old Behavioral Intention of using fintech.The implementation of digital economy through a marketplace carried out by SME entrepreneurs is in accordance with the procedures to have a positive impact at the situation the Covid-19 pandemic. So were the findings Wan (2010), SMEs are strongly encouraged to trade in e-commerce, so that they can continue to survive. Large-Scale Social Restrictions (LSSR) limit certain activities in an area that is suspected of being infected with Covid-19. Thus, many activities are carried out at home.

Old Behavioral Intention of using fintech is proven to have a positive and significant effect on New Behavioral Intention of using fintech. The corona pandemic has shifted people's behavior in shopping activities that were previously dominant offline to the online system. Changing patterns are followed by SMES players in order to survive in facing the new normal conditions. At least there are several protocol corridors that underlie the digitization of SMEs in preparation for the new normal. Online community activities are inevitable, to prevent the massive spread of Covid-19, either by doing social distancing or physical distancing (Sulistiyo, 2020).

New Normal has a positive and significant effect on New Behavioral Intention of using fintech. The implication is that there is a reduction in direct interaction in the center of the crowd. Various sectors were also affected, from large industry players to micro, 
small and medium enterprises (SMEs). Digital transformation is inevitable in the business world. The modes of communication, work patterns, business consumer behavior patterns are new and shifting. The impact of Covid-19 globally has sharply increased the adoption of digital technology in the financial industry.

The effect of New Normal on Old Behavioral Intention of using fintech is not proven to have a moderating effect on New Behavioral Intention of using fintech. SMEs in the new normal era lay in integration, such as integration of payment systems using fintech. Of course, this integration can be used immediately if SMEs join the marketplace, and have already gained experience of getting the benefits of using fintech before the Covid-19 pandemic, so that new normal conditions do not have a significant effect on increasing use of fintech. The benefits felt by SMEs by implementing the digital economy. The impact of the use of fintech that has been felt by SMEs is that they can sell their products to a wider market (Yan, 2015; Ahlstrom et al., 2020;Zehir et al., 2012).

The implication is that in the conditions of the Covid-19 pandemic with various derivative regulations issued by the government, it is highly recommended for SMEs to take advantage of fintech for their business transactions, in order to continue their business. Even for the foreseeable future, the use of fintech will benefit the business development of SMEs.

The limitations of this study are mainly the lack of data that can be collected due to limited research time and the reluctance of SMEs to fill out questionnaires. For the next researchers, perhaps they can add data to cover 34 provinces in Indonesia and if the budget is available, they can provide souvenirs in any form that motivates respondents to fill out the questionnaire.

\section{REFERENCES}

Abdurrahman, F. T. (2020). Dampak Covid-19 Terhadap Umkm Di Indonesia. Jurnal Brand, 2(1), 147-153. https://www.academia.edu/ 42672824/DampakCovid19_Terhadap_UMKM_di_Indonesia

Agus, S. (2020). Prospek Ekonomi Digital di Era New Normal. https:/ / investor.id/opinion/prospek-ekonomi-digital-di-era-new-normal

Ahlstrom, D., Arregle, J., \& Hitt, M. A. (2020). Managing Technological, Sociopolitical, and Institutional Change in the New Managing Technological, Sociopolitical, and Institutional Change in the New Normal. April. https:/ / doi.org/10.1111/joms.12569

Benuf, K. (2020). Urgensi Kebijakan Perlindungan Hukum Terhadap Konsumen Fintech Peer To Peer Lending Akibat Penyebaran Covid-19. Jurnal Rechts Vinding: Media Pembinaan Hukum Nasional, 9(2), 203. https://doi.org/ 10.33331/rechtsvinding.v9i2.427

Chang, C.-L., McAleer, M., \& Wong, W.-K. (2020). Risk and Financial Management of Covid-19 in Business, Economics and Finance. Journal of Risk and Financial Management, 13(5), 102. https:// doi.org/10.3390/jrfm13050102

Churry. (2020). The New Normal dari Kacamata Keuangan Digital. ItWorks. https:// www.itworks.id/28439/the-new-normal-dari-kacamata-keuangan-digital.html

Cindy, M. A., \& Agung, J. (2020). Efek Positif Pandemi, Konsumen \& UMKM Jadi Terbiasa 
Transaksi Digital. https:/ / doi.org/10.11693 / hyhz20181000233

Dijkstra, T. K., \& Henseler, J. (2017). Consistent and Asymptotically Normal PLS Estimators for Linear Structural Equations. Computational Statistics $\mathcal{E}$ Data Analysis, 81(1), 10-23.

Dubey, V., Sonar, R., \& Mohanty, A. (2020). FinTech, RegTech and Contactless Payments Through the Lens of COVID 19 Times. International Journal of Advanced Science and Technology, 29(6), 3727-3734. https://doi.org/https:// www. researchgate.net/publication/342663514

Fu, J., \& Mishra, M. (2020). Fintech in the Time of COVID-19: Trust and Technological Adoption During Crises. Swiss Finance Institute. https://doi.org/https://dx.doi.org/10.2139/ssrn.3588453

Gendro, W., \& Kusuma, C. K. (2020). Efek Impresi Fintech Terhadap Perilaku Keuangan SMES. Jurnal Ilmiah Manajemen Dan Bisnis, 21(April), 69-81.

Giese, J., \& Haldane, A. (2020). Covid-19 and the financial system: a tale of two crises. Oxford Review of Economic Policy, 36(Supplement_1), S200-S214. https://doi.org/10.1093/oxrep/ graa035

Hair et al. (2017). A Primer on Partial Least Square Structural Equation Modeling (PLSSEM) $2^{\text {th }}$ Edition, Los Angeles, London, New Delhi, Singapore, Washington DC, Melbourne: SAGE

Javed, A. (2020). Impact of Covid- 19 on Pakistan' s services sector. Jurnal Inovasi Ekonomi, 05(03), 107-116. https://doi.org/https://doi.org/10.22 219/jiko.v5i03.12194

Juminto, M. S. (2020). Adaptasi UMKM saat New Normal. https://www.jawapos.com/opini /24/06 /2020/adaptasi-umkm-saat-newnormal/\%0 A PANDEMI

Kasradze, T. (2020). Challenges Facing Financial Inclusion Due to the Covid-19 Pandemic. 8659(August), 63-74. https://doi.org/https:// dx.doi.org/10.26417/ejme.v3i2.p6374

Knight, E., \& Wójcik, D. (2020). FinTech, economy and space: Introduction to the special issue. Environment and Planning A, 52(March 2007), 1490-1497. https://doi.org/10.1177/0308518 X20946334

Liang, T. (2020). Handbook of Covid-19 Prevention and Treatment. (T. Liang, Ed.) Hangzhou: Alibaba Foundation

Meita, F. (2020). Dukung UMKM Menuju Digital untuk Hadapi Tantangan New Normal. https://m.fimela.com/lifestyle-relationship/read / /4280092/dukung-umkmmenuju-digital-untuk- hadapi-tantangan-new-normal

Ozili, P. K. (2020). Financial Inclusion and Fintech during COVID-19 Crisis: Policy Solutions. SSRN Electronic Journal, July. https:/ / doi.org/ 10.2139/ssrn.3585662

Putri Rusadi, F. A. R., \& Benuf, K. (2020). Fintech peer to peer lending as a financing alternative for the development MSMEs in Indonesia. Legality: Jurnal Ilmiah Hukum, 28(2), 232-244. https:// doi.org/10.22219/ljih.v28i2.12865

Ratna, Sahay. Ulrick, E. Amina, L. Purva,K. Sumiko. Majid. Kim, B. (2020). The Promise of Fintech. International Monetary Fund. No.20/09. Publication Services P.O. Box 
92780, Washington

Relman, E. (2020). Business insider Singapore. Cited Jan 28th 2020. Available on:https://www. businessinsider.sg/deadly-china-wuhan-virus spreadinghuman-to-human-officials-confirm-2020-1/?r=US\&IR=T.

Sekaran, U., \& Bougie, R. (2017). Metode Penelitian untuk Bisnis: Pendekatan PengembanganKeahlian (6th ed.). Salemba Empat.

Smeets, K., \& Zeisberger, S. (2020). How FinTech Can Help Latin America to Deal with Economic Challenges and the Covid-19 Crisis. SSRN Electronic Journal, 1-22. https:/ / doi.org/ 10.2139/ssrn.3673240

Sulistiyo, B. (2020). New Normal dan Digitalisasi UMKM. Harian Kontan. ttps://analisis. kontan.co.id/news/new-normal-dan-digitalisasi-umkm New

Tut, D. (2020). Munich Personal RePEc Archive FinTech and the Covid-19 Pandemic: Evidence from Electronic Payment Systems FinTech and the Covid-19 Pandemic: Evidence from $\begin{array}{lll}\text { Electronic Payment } & 102401 .\end{array}$ https://doi.org/https://dx.doi.org/10.2139/ssrn.3660987

Wan, L. H. (2020). Strategi Bertahan UMKM di Tengah Pandemi Covid-19. Jurnal Akuntansi \& Ekonomika, 2(1), 20-42.

WHO. (2020). WHO Director-General's remarks at the media briefing on 2019-nCov on 11 February 2020. Cited Feb 13rd 2020. Avalaible on: https://www.who.int/dg/speeches/detail/ who-director-generals-remarks-atrthe-media-briefing-on-2019-ncov-on-11-february-2020. (Feb 12th 2020).

Wiyono, G. (2020). Merancang Penelitian Bisnis dengan alat analisis SPSS 17.0 E SmartPLS 2.0 (Kedua). UPP STIM YKPN.

Wójcik, D. (2020). Geographies of finance I: Exploring FinTech - Maps and concepts. Progress in Human Geography. https:/ / doi.org/10.1177/ 0309132520952865

Yan, S. (2015). A Theoretical Framework of Competitve Advantage for Smes in China Under New Normal Economy. European Scientific Journal, 11(34), 1-12. file:///C:/Users/user ～/Downloads/6717-19562-1-PB.pdf\%0Ahttps: //eujournal.org/index.php/esj/article/download/.../6443 